\title{
Influence of Leadership Orientation and Level of Awards Against Employee Loyalty in Lancang Kuning University
}

\author{
Abrar Tanjungi*, Giatman², Ambiyar² \& Syahril2 \\ ${ }^{1}$ Faculty of Engineering, Universitas Lancang Kuning, Riau, Indonesia \\ ${ }^{2}$ Faculty of Engineering, Universitas Negeri padang, Padang, Indonesia \\ *Corresponding Author : abrar@unilak.ac.id \\ Whatsapp Number [+6281365790713]
}

How to Cite : Tanjung, A., Giatman, G., Ambiyar, A., Syahril, S.(2020).Influence of Leadership Orientation and Level of Awards Against Employee Loyalty in Lancang Kuning University. International Journal for Educational and Vocational Studies, 2 (6), 412-421. DOI: https://doi.org/10.29103/ijevs.v2i6.2697

\section{ARTICLE HISTORY}

Received: 23 February 2020

Revised: 21 April 2020

Accepted: 18 May 2020

\section{KEYWORDS}

Rewards;

Employees;

Leadership;

Data;

\section{ABSTRACT}

Human resources are people who design and produce goods or services, oversee quality, market products, allocate financial resources and formulate all strategies and objectives of the organization. Full and continuous management and utilization of existing human resources so that they can work optimally, effectively and productively in achieving organizational or company goals. Lancang Kuning University is an educational institution that has administrative and teaching and learning activities. The total number of employees or employees is 513 , consisting of 377 educators and 144 education staff. Simultaneous Influence. Based on the results of the discussion, the simultaneous influence of leadership orientation and rewards on employee loyalty is $32.1 \%$, while the remaining $67.9 \%$, while the partial effect of multiple regression analysis shows that supervision has an influence on employee work discipline by 0.435 , awards have an influence to employee loyalty of 0.279 .

This is an open access article under the CC-BY-SA license.

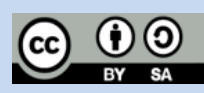

\section{INTRODUCTION}

Leaders and employees are important elements in a company that has an important role in running a company. Nowadays business development is increasingly rapid and increasingly competitive levels make companies have to improve and develop their performance in all fields. Every company has a way so that the company can survive in the midst of intense competition, one of which must be improved is human resources. Robbins and Coulter who (in T. Hermermaya, 2014: 16) "The process of coordinating work activities so that the work is completed efficiently and effectively and through others" Within the organization and company management is needed that can manage a series of components including people who are in the organization. which consists of planning, organizing, mobilizing and controlling actions. Stephen P. Robbins, Mary Coulter stated that management involves coordination and oversees other work activities so that their activities are completed effectively and efficiently. The meaning of efficient itself is getting the most output from the minimum possible input, while effective is "doing the right thing", which is doing a job that can help the organization achieve its goals (2016). Marwansyah also stated that Human Resource Management can be interpreted as the utilization of human resources within the organization, which is carried out through the functions of human resource planning, career planning and development, compensation and welfare, and industrial relations (Marwansyah, 2016: 16).

Human resources are the withdrawal, selection, development, maintenance, and use of human resources to achieve both individual and organizational goals (T. Handoko, 2014: 20). Meanwhile, according to (Samsudin, 2014: 20) Human resources are people who design and produce goods or services, oversee quality, market products, allocate financial resources and formulate all strategies and objectives of the organization. According to (Samsudin, 2014: 23) there is an essential thing from human resource management is the management and utilization of full and continuous human resources available so that they can work optimally, effectively and productively in achieving the goals of the organization or company.

Lancang Kuning University is one of the private universities in LLDIKTI region X. It was founded by the 
Raja Ali Haji Foundation which was then initiated by Riau Governor H. Imam Munandar. Since its establishment in 1982 until now it has 9 Faculties with 18 undergraduate study programs and 2 postgraduate study programs. Lancang Kuning University is an educational institution that has administrative and teaching and learning activities. The total number of employees or employees is 513, consisting of 377 educators and 144 education staff.

\section{LITERATURE REVIEW}

Leadership is the most important factor in an organization. To understand the leadership style we first know the definition of leadership according to experts is as follows, According to Stogdi (in Dr. M. Sobry Sutikno, 2014: 15), "There are almost as many definitions of leadership as the number of people who have tried to define it." Stogdill states that, "Leadership as a management concept can be formulated in various definitions depending on where the thinking starts." Leadership in organizations is directed to influence the people they lead, so they are willing to act as expected or directed by others who lead it (Sutikno, 2014: 22). Leadership according to (Kartono, 2014: 32) is an aspirational force, a spirit of enthusiasm, and a creative moral force, which is able to influence members to change attitudes, so they become conform to the desires of the leader. Meanwhile according to (Rivai, 2015: 19) Leadership is a process of influencing in determining the organization, motivating followers' behavior to achieve goals, influencing to improve the group and its culture. Then it can be concluded that leadership is a behavior with a specific purpose to influence the activities of group members so as to achieve common goals that are designed to provide benefits to individuals and organizations.

\section{Leadership Orientation}

Leadership orientation can be interpreted also with leadership style, leadership style According to (Thoha, 2013: 49) that Leadership Style is the norm of behavior used by someone when the person is trying to influence the behavior of others as he sees it. Furthermore according to (Rivai, 2014: 42) states Leadership Style is a set of characteristics used by leaders to influence subordinates so that organizational goals are achieved or it can also be said that leadership style is a pattern of behavior and strategy that is liked and often applied by a leader.

\section{Award level}

The definition of compensation is as follows all income in the form of money, direct or indirect goods received by employees in return for services provided to the company (Malayu S.P. Hasibuan, 2014: 118). According to (Dessler, 2015: 302) Compensation is any form of payment or appreciation given to employees arising from their work.
Meanwhile according to Marihot Tua E.H. (in Sunyoto, 2015) defines compensation as a whole remuneration received by employees as a result of carrying out work in the organization in the form of money or other, which can be in the form of salaries, wages, bonuses, incentives and health benefits, holiday allowances, meal allowances, paid leave and others.

\section{METHODS}

\section{Data Types and Sources}

The types and sources of data used in this study are as follows:

\section{a. Primary Data}

Primary data is data that is directly obtained from the first data source at the study site (Bungin, 2015). Primary data is data that is processed and presented by this study. Like the results of questionnaires conducted by researchers, in the form of data obtained from respondents.

\section{b. Secondary Data}

Secondary data is research data obtained indirectly through intermediary media (produced by other parties) or used by other institutions that are not processors, but can be utilized in a particular study. Secondary data is generally in the form of published records or data documentation reports.

\section{Population and Sample}

\section{a. Population}

Population is all the component elements of concern in a study or the whole set of elements used in making conclusions. Element is defined as the subject of measurement or known as a research unit. The population in this study were employees at the University of Lancang Kuning, as many as 80 people. The selection of employees only as a study population because it can facilitate research and not take too much time. In addition, this population can also represent all system work units in the company.

\section{b. Sample}

In this study, samples were taken by employees at the Lancang Kuning University. Based on a survey conducted, then in sampling, the researcher decided to use a random sampling technique that includes people in the population, so that each member of the population has the same right to be a respondent in this study. The sample in this study were 80 employees at the Lancang Kuning University, Pekanbaru.

\section{Data Collection Technique}

In this paper to collect the data needed, the authors conduct research using the methods: 


\section{Observation}

Observation is a data collection technique that has specific characteristics when compared to other techniques, namely interviews and questionnaires. Retrieval of data is done by direct observation to Pekanbaru Lancang University with the aim of reviewing the problem.

\section{Documentation}

Retrieval of data is done by asking the company about secondary data in the form of the number of employees, the average incentive, and other reports relevant to research.

\section{Questionnaire}

Distributing this questionnaire is intended to obtain descriptive data to test hypotheses and to obtain the data used a questionnaire that is closed, ie statements made in such a way that respondents are limited in giving answers to only a few alternatives with a Likert scale.

\section{RESULTS AND DISCUSSION}

The measurement of variables is carried out using a Likert scale using the scoring method as follows: Figures 1 indicate that the respondent did not support the question given. While number 5 shows that the respondent supports the question given.

Tabel 1. Scoring Questionnaire

\begin{tabular}{clc}
\hline No. & \multicolumn{1}{c}{ Category } & Score \\
\hline 1 & Strongly agree & 5 \\
\hline 2 & Agree & 4 \\
\hline 3 & Doubtful & 3 \\
\hline 4 & Disagree & 2 \\
\hline 5 & Strongly disagree & 1 \\
\hline
\end{tabular}

\section{Definition of Variable Operations}

Prior to data collection, the researcher first defined the variables to be examined including the indicators and measurement scales used as follows:

Tabel 2. Definition of Variable Operations

\begin{tabular}{llll}
\hline No. & Variable & Indicator & $\begin{array}{c}\text { Scale of } \\
\text { Measurement }\end{array}$ \\
\hline $1 . \quad \begin{array}{l}\text { Leadership } \\
\text { Orientation (X1) is }\end{array}$ & $\begin{array}{l}\text { 1.Decision } \\
\text { Making Ability }\end{array}$ & \\
behavior and & 2.Motivating & \\
strategy, as a result & Ability & Likert \\
of a combination of & 3.Communication & \\
philosophy, skills, & Skills & \\
traits, attitudes, & 4.Ability to & \\
which are often & Control & \\
applied from a leader & Subordinates & \\
when he tries to & & \\
influence the & & \\
performance of his & & \\
\hline
\end{tabular}

\begin{tabular}{|c|c|c|c|}
\hline & $\begin{array}{l}\text { subordinates } \\
\text { (Rorimpandey, 2013). }\end{array}$ & & \\
\hline 2. & $\begin{array}{l}\text { Level of Appreciation } \\
\text { (X2) Level of } \\
\text { Appreciation / } \\
\text { appreciation is one of } \\
\text { them indicated by the } \\
\text { award of } \\
\text { compensation. } \\
\text { Compensation is any } \\
\text { form of payment or } \\
\text { appreciation given to } \\
\text { employees arising } \\
\text { from their work } \\
\text { (Dessler, 2015: 302) }\end{array}$ & $\begin{array}{ll}\text { 1. } & \text { Giving } \\
\text { commissions } \\
\text { applied by } \\
\text { the company } \\
\text { management } \\
\text { is fair } \\
\text { 2. The company } \\
\text { gives a bonus } \\
\text { if it is able to } \\
\text { achieve the } \\
\text { expected } \\
\text { performance } \\
\text { 3. Awarding in } \\
\text { accordance } \\
\text { with the } \\
\text { responsibiliti } \\
\text { es of the } \\
\text { employee's } \\
\text { work } \\
\text { Job } \\
\text { promotions } \\
\text { given by } \\
\text { company } \\
\text { management } \\
\text { to employees }\end{array}$ & Likert \\
\hline 3. & $\begin{array}{l}\text { Employee Loyalty (Y) } \\
\text { Loyalty is the } \\
\text { willingness of } \\
\text { employees with all } \\
\text { abilities, skills, } \\
\text { thoughts and time to } \\
\text { participate in } \\
\text { achieving company } \\
\text { goals and keep } \\
\text { company secrets and } \\
\text { not take actions that } \\
\text { harm the company as } \\
\text { long as the person is } \\
\text { still an employee. } \\
\text { (Robbins, 2014) }\end{array}$ & $\begin{array}{l}\text { 1. Stay in the } \\
\text { organization } \\
2 \text {. Willing to work } \\
\text { overtime to get } \\
\text { work done. } \\
\text { 3. Keep company } \\
\text { business secrets. } \\
\text { 4. Want to follow } \\
\text { directions or } \\
\text { instructions } \\
\text { 5. The level of } \\
\text { honesty in } \\
\text { carrying out each } \\
\text { task given }\end{array}$ & Likert \\
\hline
\end{tabular}

\section{Data Analysis Method}

\section{a. Descriptive Statistical Analysis}

Descriptive statistical analysis in a study is basically a process of transforming research data in the form of tabulations so that it is easy to understand and interpret. The tabulation presents a summary, arrangement or arrangement of data in the form of numerical tables and graphs. Descriptive statistics are generally used by researchers to provide information about the characteristics of the main research variables and respondent demographic data. Descriptive statistical analysis used in this study is to use a frequency distribution table that shows the minimum value, maximum value, mean value and standard deviation that aims to provide an overview or description of the research variables consisting of work discipline, work environment ,organizational culture and employee performance. Meanwhile, to describe the demographics of respondents consisting of gender, length of work, position and level of education used frequency distribution tables and percentages. Descriptive analysis, used to describe the 
scores of variable $\mathrm{X}$ and $\mathrm{Y}$ as well as their position and answer research objectives that are descriptive. This analysis is carried out through a continuum review and comparison of the average sample data.

\section{b. Data Quality Test}

The accuracy of testing a hypothesis is very dependent on the quality of the data used in the test. The quality of research data is determined by the quality of the instruments used to collect data (Sugiyono, 2016: 147). Data quality tests include validity and reliability tests. To determine the validity and reliability test, researchers used calculations with the help of SPSS (Statistical Product and Service Solution) for Windows ver 17 to obtain targeted results.

\section{Test Validity}

Validity test is performed to determine whether a measuring instrument has carried out its measurement function. Validity indicates the accuracy and accuracy of the measuring instrument in carrying out its measuring function or a measurement scale is called valid if it does what it should do and measures what it should measure. Validity test aims to determine the accuracy and reliability of the questionnaire which means that the questionnaire is able to measure what should be measured (Ghozali, 2013: 52). Validity test in this study was carried out using the Pearson Product Moment formula with the help of SPSS (Statistical Product and Service Solution) for Windows ver 17.

A questionnaire is said to be valid if it meets the following criteria :

1. Results $r_{\text {count }}>r_{\text {table }}$

2. Significance value $(p)<0.05$

\section{Reliability Test}

Reliability testing is related to the problem of trust in the instrument. An instrument can have a high level of confidence (consistent) if the results of testing the instrument show permanent results. Thus, the problem of reliability is carried out to determine the level of stability of a measuring instrument. The measurement results can be trusted if used in several measurements of the same group of subjects obtained from the same relative results, as long as the aspects measured in the subject do not change. The most common way to measure reliability is to use alpha coefficients. Alpha coefficients can be measured using the Cronbach Alpha statistical test. A variable is said to be reliable if it gives a Cronbach Alpha value> 0.6 (Ghozali, 2013: 47). The reliability test was also carried out with the help of SPSS (Statistical Product and Service Solution) software for Windows of version 17.

\section{Classical Assumption Test}

Before testing hypotheses using multiple regression analysis, classic assumption testing is needed. There are four most important assumptions as conditions for using the regression method. These assumptions are assumptions of normality, multicollinearity and heterokedastisitas. This test needs to be done because of the consequences that might occur if the assumptions cannot be met.

\section{a. Normality test}

Normality test aims to assess the distribution of data in a group of data or variables, whether the distribution of data is normally distributed or not. Normality Test aims to test whether in the regression model, confounding or residual variables have a normal distribution. As it is known that the $\mathrm{t}$ and $\mathrm{F}$ test assumes that the residual value follows the normal distribution. If this assumption is violated then the statistical test becomes invalid for a small sample size. There are two ways to detect whether residuals are normally distributed or not, namely by graphical analysis and statistical tests. Testing using the One Sample Kolmogorov-Smirnov Test (K-S) statistical test. If the K-S significance value is greater than 0.05 , then the data is normally distributed (Ghozali, 2013: 29).

\section{b. Heterokedasticity Test}

The heteroscedaticity test aims to test whether in the regression model there is an unequal variance from the residuals of one observation to another, if the variance from the residuals of one observation to another observation is fixed, then it is called homoskedaticity. However, if it is different, it is called heteroscedaticity. A good regression model is homoskedatisitas. The test used is the glacier test where this test is done by regressing the absolute residual value of all independent variables. If the $\mathrm{p}$-value on the $\mathrm{t}$ test results there is a small regression coefficient from the value of 0.05 , the residual value occurs heteroscedaticity symptoms. Meanwhile, if the $\mathrm{p}$-value on the $\mathrm{t}$ test results there is a regression coefficient greater than the value of 0.05 , the residual value does not occur heteroscedaticity symptoms.

\section{c. Multicollinearity Test}

According to (Ghozali, 2013: 105), multicollinearity test aims to test whether the regression model found a correlation between independent variables. A good regression model should not occur correlation between independent variables. To detect multicollinearity can see the value of tolerance and Variance Inflation Factor (VIF). If there are no independent variables that have a torelance value of less than 0.10 or a VIF of more than 10 , then there is no multicollinearity between the independent variables in the regression model. Conversely, if there are independent variables that have a tolerance value of less than 0.10 or a VIF of more than 10 , there will be multicollinearity disorders in the study. 


\section{Hypothesis Test}

To test the hypothesis in this study using multiple linear analysis. Multiple linear regression analysis is used to determine the effect of two or more independent variables with one dependent variable. Calculation of multiple linear regression analysis in this study was tested using SPSS (Statistical Product and Service Solution) software for Windows ver 17. Hypothesis testing in this study was tested using Standardized Coefficients test values. Leadership orientation has a positive effect on appreciation. The effect is positive and significant by looking at the t-count value and sig 0.00 is smaller than a 0,000 . This test is used to determine whether the independent variable partially influences the dependent variable

This study has five hypotheses tested using multiple linear regression analysis, namely as follows:

\section{The First Hypothesis (H1)}

The first hypothesis (H1) of this study is Allegedly the Effect of Leadership Orientation on Employee Loyalty, the research hypotheses to be tested are:

H0 :Leadership Orientation does not affect Employee Loyalty.

H1 : Leadership Orientation influences Employee Loyalty.

\section{The Second Hypothesis $(\mathrm{H} 2)$}

The second hypothesis (H2) of this study is the Influence of Estimated Level of Rewards on Employee Loyalty, the research hypothesis to be tested are:

H0: The level of appreciation does not affect employee loyalty.

H1: The level of appreciation influences employee loyalty.

The regression equation in this study is as follows:

$$
\mathrm{Y}=\mathrm{a}+\mathrm{b} 1 \mathrm{X} 1+\mathrm{b} 2 \mathrm{X} 2
$$

\section{Information :}

Y: The dependent variable is Employee Loyalty

a: The regression equation constant

b1-b2: coefficient

e: Interference Variable (error)

X1: Leadership Orientation independent variable

X2: Award Level independent variable

\section{5) Determination Test (R2)}

The coefficient of determination (KD) is used to test the goodness-fit of the regression model. The coefficient of determination is to see how much the independent variables together can provide an explanation of the independent variables. Where the higher R2 value explains that the independent variable the better its ability to explain the dependent variable in the study. The smaller the value of R2 means the less ability of independent variables to explain the dependent variable in the study. Things to consider about the coefficient of determination are as follows: a. R2 values must range from 0 to 1

b. If $\mathrm{R} 2=1$ means there is a perfect match of the independent variables explaining the dependent variable.

If $\mathrm{R} 2=0$ means there is no relationship at all between the independent variables to the dependent variable

\section{DISCUSSION}

\section{Characteristics of Respondents}

Data processing on the profile of respondents is intended to find out the general description of respondents in terms of gender, education and work experience. From a number of respondents as many as 80 people through the questionnaire obtained the following results:

\section{Respondents by Gender}

Based on the results of respondents' answers based on gender obtained the Table 3 .

Table 3. Respondents by Gender

\begin{tabular}{clcc}
\hline No & Gender & Amount & Percentage (\%) \\
\hline 1 & Male & 48 & 60 \\
\hline 2 & Female & 32 & 40 \\
\hline & Total & 80 & 100
\end{tabular}

Source: Processed Data

Based on the table above it can be seen that the composition of respondents by sex is more dominant than male when compared to women The composition of men is $60 \%$ while women are only $40 \%$.

\section{Respondents Based on Work Experience}

Based on the results of respondents' answers based on work experience obtained the from Table 4.

Table 4. Respondents Based on Work Experience

$\begin{array}{cccc}\text { No. } & \begin{array}{c}\text { Years of } \\ \text { service }\end{array} \text { Category } & \text { Amount } & \begin{array}{c}\text { Percentage } \\ (\%)\end{array}\end{array}$

\begin{tabular}{rcccc}
\hline 1 & $<5$ & Low & 28 & 35 \\
\hline 2 & $\geq 5-10$ & enough & 42 & 52,5 \\
\hline 3 & $>10$ & High & 10 & 12,5 \\
\hline & Total & & 80 & 100 \\
\hline
\end{tabular}

Source: Processed Data

Based on the table above it is known that the most dominant respondent with a working period of 5 to 10 years is $52.5 \%$. The rest with a 10 -year tenure of $12.5 \%$ and a 5 -year tenor of $35 \%$. This shows that the majority of respondents have adequate work experience. But there are still many respondents who have low experience.

\section{Validity and Reliability}

Based on the rules of the study, the questionnaire or questionnaire or instrument used as a measurement tool for these variables must meet the criteria of Valid and Reliable, it is necessary to test as necessary. Testing of 
validity is intended to check whether the items in the instrument are really able to provide the appropriate (data) size (data) as desired by the researcher. Testing of validity will be used $\mathrm{t}$ test for the simple correlation coefficient (Pearson) between the scores on each item with the total score of these items. An item is declared valid if the significance level of the Pearson correlation coefficient is $\leq 0.03$. While the reliability test of the instrument is intended to find out whether the questionnaire is really consistent (steady) if used to measure the same thing over and over again. Tests on the reliability of the questionnaire were carried out using Cronbach's Alpha coefficients based on price variance. A questionnaire is declared reliable if the Cronbach Alpha Coefficient value> 0.6. To find out in more detail the results of the validity and reliability of the transformational leadership statement items contained in the research questionnaire can be seen in the table 5 .

Table 5. Leadership Orientation Validity and Reliability (X1)

\begin{tabular}{cccc}
\hline $\begin{array}{c}\text { Item } \\
\text { Questions }\end{array}$ & $\begin{array}{c}\text { Total } \\
\text { Correlation }\end{array}$ & $\begin{array}{c}\text { Cronbach's } \\
\text { Alpha }\end{array}$ & Description \\
\hline $\mathrm{X} .1$ & .679 & .918 & $\begin{array}{c}\text { Valid \& } \\
\text { Reliable }\end{array}$ \\
\hline $\mathrm{X} .2$ & .865 & .854 & $\begin{array}{c}\text { Valid \& } \\
\text { Reliable }\end{array}$ \\
\hline $\mathrm{X} .3$ & .818 & .872 & $\begin{array}{c}\text { Valid \& } \\
\text { Reliable }\end{array}$ \\
\hline $\mathrm{X} .4$ & .816 & .873 & $\begin{array}{c}\text { Valid \& } \\
\text { Reliable }\end{array}$ \\
\hline & Cronbach's Alpha $=0,908$ & \\
\hline
\end{tabular}

Source: Processed Data

As illustrated in the table above, the magnitude of corrected product moment corrections for each question item is greater than 0.3 , which means significant. It can be concluded that the question items in the Leadership Oriented Variation questionnaire (X1) are Valid. The results of the Alpha Cronbach's reliability coefficient calculation are also known to have a value of 0.908 , while the limit value (critical value) of 0.60 . It can be concluded that the Leadership Orientation variable questionnaire is reliable and feasible to use. The results of the validity and reliability can be see in the table 6 .

Table 6. Validity and Reliability Variable Awards (X2)

\begin{tabular}{cccc}
\hline $\begin{array}{c}\text { Item } \\
\text { Questions }\end{array}$ & $\begin{array}{c}\text { Total } \\
\text { Correlation }\end{array}$ & $\begin{array}{c}\text { Cronbach's } \\
\text { Alpha }\end{array}$ & Description \\
\hline $\mathrm{X} .1$ & .556 & .696 & $\begin{array}{c}\text { Valid \& } \\
\text { Reliable }\end{array}$ \\
\hline $\mathrm{X} .2$ & .596 & .681 & $\begin{array}{c}\text { Valid \& } \\
\text { Reliable }\end{array}$ \\
\hline $\mathrm{X} .3$ & .634 & .661 & $\begin{array}{c}\text { Valid \& } \\
\text { Reliable }\end{array}$ \\
\hline $\mathrm{X} .4$ & .468 & .740 & $\begin{array}{c}\text { Valid \& } \\
\text { Reliable }\end{array}$ \\
\hline
\end{tabular}

Cronbach's Alpha = 0,755

Source: Processed Data

As illustrated in the table above, the magnitude of corrected product moment corrections for each question item is greater than 0.3 , which means significant. It can be concluded that the question items in the Award variable questionnaire (X2) are Valid. The results of the Alpha Cronbach's reliability coefficient calculation are also known to have a value of 0.755 , while the limit value (critical value) of 0.60 . It can be concluded that the Award variable questionnaire is reliable and feasible to use. The results of the validity and reliability of the question items for the Employee Loyalty (Y) variable are illustrated as follows:

Table 7. Variability and Reliability of Employee Loyalty (Y)

\begin{tabular}{cccc}
\hline $\begin{array}{c}\text { Item } \\
\text { Questions }\end{array}$ & $\begin{array}{c}\text { Total } \\
\text { Correlation }\end{array}$ & $\begin{array}{c}\text { Cronbach's } \\
\text { Alpha }\end{array}$ & Description \\
\hline Y.1 & .681 & .899 & Valid \& Reliable \\
\hline Y.2 & .838 & .843 & Valid \& Reliable \\
\hline Y.3 & .785 & .863 & Valid \& Reliable \\
\hline Y.4 & .794 & .860 & Valid \& Reliable \\
\hline \multicolumn{4}{c}{ Cronbach's Alpha $=0,897$} \\
\hline
\end{tabular}

Source: Processed Data

As illustrated in the table above, the magnitude of corrected product moment corrections for each question item is greater than 0.3 , which means significant. It can be concluded that the question items in the Leadership Oriented Variation questionnaire (X1) are Valid. The results of the Alpha Cronbach's reliability coefficient calculation are also known to have a value of 0.897 , while the limit value (critical value) of 0.60 . It can be concluded that the Leadership Orientation variable questionnaire is reliable and feasible to use.

\section{Variable Description}

\section{a. Leadership Orientation (X1)}

The definition of leadership has undergone changes in development and shift. In the old era leadership orientation was defined as a style of ability and readiness that someone had to influence others, by motivating, moving, directing, inviting, guiding and if necessary forcing them to do or not do something. From the respondents' answers to leadership orientation, the results are as shown in the table 8. 
Table 8. Respondents' Responses to Leadership Orientation

\begin{tabular}{llcccccc}
\hline \multirow{2}{*}{ No. } & \multirow{2}{*}{ Question Indicator } & $\begin{array}{c}\text { Strongly } \\
\text { Agree }\end{array}$ & Agree & $\begin{array}{c}\text { Quitee } \\
\text { Agree }\end{array}$ & Disagree & Very Disagree & Average \\
\cline { 3 - 7 } & & 1 & 4 & 3 & 2 & 1 \\
\hline 1 & Decision Making Ability & 9 & 49 & 22 & 0 & 0 & 3,83 \\
\hline 2 & Motivating Ability & 24 & 40 & 16 & 0 & 0 & 4,1 \\
\hline 3 & Communication Skills & 22 & 43 & 15 & 0 & 0 \\
\hline 4 & Ability to Control Subordinates & 17 & 48 & 15 & 0 & 0 \\
\hline
\end{tabular}

Source: Processed Data

\section{b. Award (X2)}

One of the level of appreciation/appreciation is shown by giving compensation. Compensation is an important function in human resource management (HRM). Because compensation is one of the most sensitive aspects of work relations. Cases that occur in employment relationships contain compensation issues and various related aspects, such as benefits, compensation increases, compensation structures and compensation scale. Compensation includes direct cash payments, indirect payments in the form of employee benefits, and incentives to motivate employees to work hard to achieve higher productivity. If managed properly, then this compensation can help companies to achieve higher productivity for their employees. From the respondent's answer to the award obtained the results as illustrated in the table 9 .

Table 9. Respondents' Responses to Awards

\begin{tabular}{|c|c|c|c|c|c|c|c|}
\hline \multirow{2}{*}{ No } & Question & SS & $\mathrm{S}$ & $\mathrm{CS}$ & TS & STS & \multirow{2}{*}{ Average } \\
\hline & Indicator & 1 & 4 & 3 & 2 & 1 & \\
\hline 1 & $\begin{array}{l}\text { The granting of } \\
\text { commissions } \\
\text { applied by } \\
\text { company } \\
\text { management is } \\
\text { fair }\end{array}$ & 17 & 47 & 9 & 0 & 0 & 4,08 \\
\hline 2 & $\begin{array}{l}\text { The company } \\
\text { gives a bonus if it } \\
\text { is able to achieve } \\
\text { the expected } \\
\text { performance }\end{array}$ & 6 & 57 & 17 & 0 & 0 & 3,86 \\
\hline 3 & $\begin{array}{l}\text { Giving awards } \\
\text { that are in } \\
\text { accordance with } \\
\text { the work } \\
\text { responsibilities of } \\
\text { employees }\end{array}$ & 29 & 33 & 18 & 0 & 0 & 4,14 \\
\hline 4 & $\begin{array}{l}\text { Job promotions } \\
\text { given by company } \\
\text { management to } \\
\text { employees }\end{array}$ & 7 & 57 & 16 & 0 & 0 & 3,89 \\
\hline
\end{tabular}

Source: Processed Data

\section{a. Employee Loyalty}

Loyalty is the willingness of employees with all the abilities, skills, thoughts and time to participate in achieving company goals and keep company secrets and not take actions that harm the company as long as the person is still an employee. Employee loyalty can be created from several aspects of construction, which are marked by the identification of an employee with company goals and with work ethics. The loyalty of an employee can be demonstrated through the feelings of an individual to join the company and become a colleague, the desire to help the leadership of the company, act according to work ethics and professionalism and be loyal to the company when it is critical. From the respondents' answers to employee loyalty, the results are as shown in the table 10.

Table 10. Respondents' Responses to Employee Loyalty

\begin{tabular}{clcccccc}
\hline \multirow{2}{*}{ No. } & $\begin{array}{l}\text { Question } \\
\text { Indicator }\end{array}$ & SS & S & CS & TS & STS & \multirow{2}{*}{ Average } \\
\cline { 2 - 5 } & 1 & 4 & 3 & 2 & 1 & \\
\hline 1 & $\begin{array}{l}\text { Staying in the } \\
\text { organization }\end{array}$ & 7 & 48 & 25 & 0 & 0 & 3,78 \\
\hline \multirow{2}{*}{2} & $\begin{array}{l}\text { Willing to work } \\
\text { overtime to get } \\
\text { work done. }\end{array}$ & 21 & 40 & 19 & 0 & 0 & 4,03 \\
\hline & $\begin{array}{l}\text { Keep company } \\
\text { business } \\
\text { secrets. }\end{array}$ & 29 & 33 & 18 & 0 & 0 & 4,04 \\
\hline & $\begin{array}{l}\text { Want to follow } \\
\text { directions or } \\
\text { instructions }\end{array}$ & 19 & 45 & 16 & 0 & 0 & 3,96 \\
\hline
\end{tabular}

Source: Processed Data

\section{Classical Assumption Test}

The results of the data description of the average score of respondents' answers cannot be used as a basis for drawing conclusions about the influence of leadership orientation and appreciation for employee loyalty. For this reason, a series of tests on hypotheses is needed.

\subsection{Data Normality}

The analyzed data must have a normal (symmetrical) distribution, the normality of the data can be tested using a non parametric statistical approach. Testing the residual normality can be seen from the normal P-P plot graph as illustrated. 


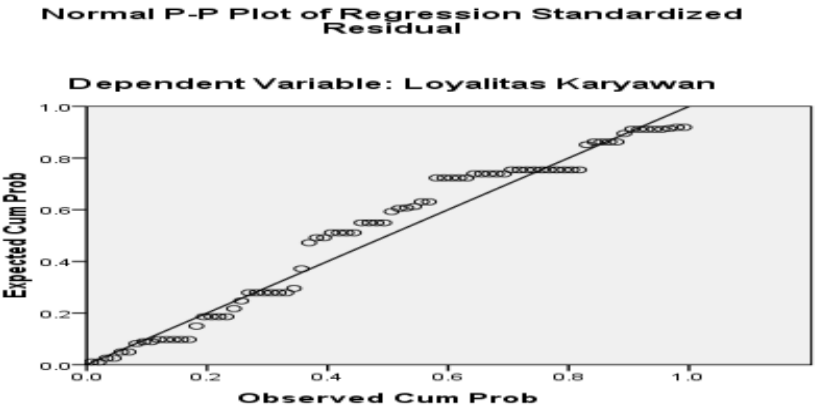

Fig.1. Testing the residual normality can be seen from the normal P-P plot graph

Based on the normal plot graph display in the picture above, visible points around are in a straight line across. Thus it can be concluded that the residual value follows the normal distribution. In addition, it can also be proven by the Kolmogorov-Smirnov statistical test where the overall value of the asym variable Sig. (2-tailed)>0.05. Thus all data meets the normality assumption.

\section{Multicolearity Test}

A good regression model should not have a correlation between independent variables. Multicollinearity can be tested through tolerance values with a variation in inflation factor (VIF). Tolerance limit $\mathrm{a}=5 \%$, if $\mathrm{VIF}<10$ then the model does not have multicollinearity. The test results for all variables can be seen in the table 11 .

Table 11. Multicollinearity Test Results

\begin{tabular}{|c|c|c|c|}
\hline & \multicolumn{3}{|c|}{ Coefficients a } \\
\hline & \multirow{2}{*}{ Model } & \multicolumn{2}{|c|}{ Collinearity Statistics } \\
\hline & & Tolerance & VIF \\
\hline \multirow[t]{4}{*}{1} & (Constant) & & \\
\hline & Leadership & ,292 & 3,421 \\
\hline & Orientation & & \\
\hline & Reward & ,292 & 3,421 \\
\hline
\end{tabular}

\section{a. Dependent Variable : Employee Loyalty}

Based on the table above shows that the $\mathrm{V}$ number $<10$, meaning that all variables are free from the element of multicollinearity. Thus the assumption of the absence of multicollinearity has been fulfilled.

\section{Heteroscedasticity Test}

The test is carried out to determine whether there are any deviations from the classical assumption of heteroscedasticity, namely the variance in residual variance for all observations in the regression model. Testing the presence or absence of heteroscedasticity on each independent variable using the Scatterplot graph.

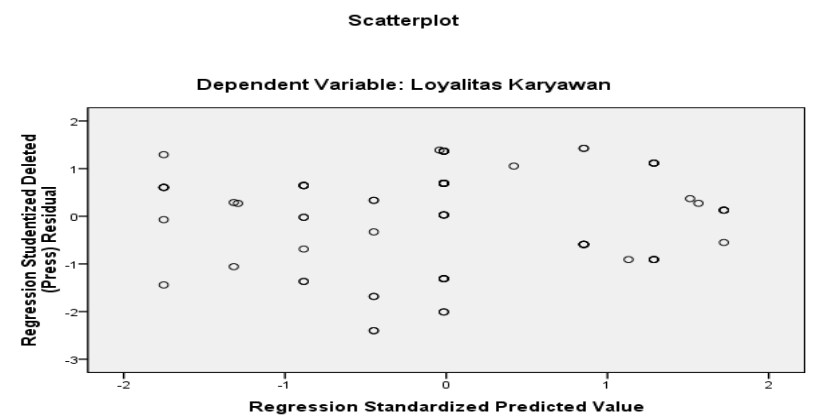

Fig. 2. Testing the presence or absence of heteroscedasticity on each independent variable using a Scatterplot chart

The scatterplot graph above shows that there are no clear patterns and points spread above and below the numbers on the $\mathrm{Y}$ axis. It can be concluded that the instrument used on all variables is free from heteroscedasticity and is suitable for use.

\section{Hypothesis Testing}

The results of the data description of the average score of respondents' answers cannot be used as a basis for drawing conclusions about the influence of discipline and motivation on employee loyalty. For this reason, a series of tests on hypotheses is needed, as follows:

\section{Testing the Coefficient of Determination (R2)}

The coefficient of determination (R2) essentially measures how far the model's ability to explain variations in independent variables. From the results of multiple linear regression analysis obtained in table 12 .

Table 12. Test Results for the Coefficient of Determination

Model Summary b

\begin{tabular}{|c|l|l|l|l|}
\hline Model & $\mathrm{R}$ & R Square & $\begin{array}{l}\text { Adjusted } \\
\mathrm{R} \text { Square }\end{array}$ & $\begin{array}{l}\text { Std. Error of the } \\
\text { Estimate }\end{array}$ \\
\hline 1 & $.582 \mathrm{a}$ &, 338 &, 321 & 1,51171 \\
\hline
\end{tabular}
a. Predictors:
(Constant), Awards,
Leadership Orientation
b. Dependent Variable: Employee Loyalty

Based on the table above, we know the value of Adjusted R. Square is 0.321 . This means that $32.1 \%$ of the Employee Loyalty (Y) variable can be explained by the Leadership Orientation (X1) and Reward (X2) variables. While the remaining $67.9 \%$ is explained by other variables outside this research model. 
Table 13. Statistical Test Results F

\begin{tabular}{|c|c|c|c|c|c|c|}
\hline \multicolumn{7}{|c|}{ ANOVA $^{b}$} \\
\hline & Model & $\begin{array}{l}\text { Sum of } \\
\text { Squares }\end{array}$ & Df & $\begin{array}{l}\text { Mean } \\
\text { Square }\end{array}$ & $\mathrm{F}$ & Sig. \\
\hline \multirow{3}{*}{1} & Regression & 89,984 & 2 & 44,992 & 19,688 & $.000^{\mathrm{a}}$ \\
\hline & Residual & 175,966 & 77 & 2,285 & & \\
\hline & Total & 265,950 & 79 & & & \\
\hline
\end{tabular}

a.Predictors: (Constant), Awards, Leadership Orientation

b.Dependent Variable: Employee Loyalty

Based on the above table it can be seen that the model used has an F-count value of $19.668>$ F-table of 3.441, with a sig test of 0.000 , smaller than alpha a 0.05 so that testing of this hypothesis is proven then $\mathrm{Ha}$ is accepted and Ho is rejected.

\section{Multiple Regression}

The results of multiple linear regression based on processed SPSS data are illustrated in table 13.

Table 13. Results of Multiple Regression

Coefficients $^{\mathrm{a}}$

\begin{tabular}{|c|c|c|c|c|c|c|}
\hline & \multirow[t]{2}{*}{ Model } & \multicolumn{2}{|c|}{$\begin{array}{l}\text { Unstandardized } \\
\text { Coefficients }\end{array}$} & \multirow{2}{*}{$\begin{array}{c}\begin{array}{c}\text { Standardiz } \\
\text { ed } \\
\text { Coefficients }\end{array} \\
\text { Beta }\end{array}$} & \multirow[t]{2}{*}{$\mathrm{t}$} & \multirow[t]{2}{*}{ Sig. } \\
\hline & & B & $\begin{array}{l}\text { Std. } \\
\text { Error }\end{array}$ & & & \\
\hline \multirow{3}{*}{1} & (Constant) & 8,545 & 1,239 & & 6,899 & ,000 \\
\hline & $\begin{array}{l}\text { Leadership } \\
\text { Orientation }\end{array}$ & ,435 & , 135 &, 552 & 3,221 & ,002 \\
\hline & Reward & ,279 & ,138 &, 035 & 202 &, 040 \\
\hline
\end{tabular}

a. Dependent Variable:

Employee Loyalty

Based on the coefficients table can be seen the relationship of each variable directly by looking at the value of Standardized Coefficients of 0.552 and 0.035 or with the equation

$$
\mathrm{Y}=8,545+0,435(\mathrm{X} 1)+0,279(\mathrm{X} 2)
$$

Based on the multiple linear regression equation above can be explained in detail:

a. A constant value of 8.545 , meaning that if the leadership orientation and rewards are in a constant state (permanent) then employee loyalty is worth 8,545 units.

b. The leadership orientation coefficient (b1) is 0.435 , meaning that if leadership orientation is increased by 1 unit while rewards are in a constant state (fixed), employee loyalty increases or by 0.435 units. Thus the leadership orientation has a positive effect on employee loyalty.

c. The coefficient of award (b2) is 0.279 , meaning that if the award is increased by 1 unit while the leadership orientation is in a constant state (constant), employee loyalty can increase or by 0.279 units. Thus it can be said that rewards have a positive effect on employee loyalty. d. The dominant variable influencing employee loyalty is leadership orientation with a contribution of 43.5\%.Then based on the results of testing to see the effect of leadership orientation on rewards directly (partial).

Table 15. Results Partially

Coefficients $^{\mathrm{a}}$

\begin{tabular}{lcccccc}
\hline \multirow{2}{*}{ Model } & \multicolumn{2}{c}{$\begin{array}{c}\text { Unstandardize } \\
\mathrm{d} \text { Coefficients }\end{array}$} & $\begin{array}{c}\text { Standardized } \\
\text { Coefficients }\end{array}$ & $\mathrm{t}$ & Sig. \\
\cline { 2 - 7 } & $\mathrm{B}$ & $\begin{array}{c}\text { Std. } \\
\text { Error }\end{array}$ & Beta & & \\
\hline 1 & (Constant) & 8,618 & 1,178 & & 7,316 &, 000 \\
\cline { 2 - 7 } & $\begin{array}{l}\text { Leadership } \\
\text { Orientation }\end{array}$ &, 458 &, 073 &, 581 & 6,311 &, 000 \\
\hline
\end{tabular}

a.Dependent Variable:

Reward

With the value of Standardized Coefficients 0.458 this means that if the leadership orientation is increased by one unit, the award increases by 0.458 units, leadership orientation has a positive effect on rewards. The effect is positive and significant by looking at the t-value of 6.311 with sig 0.00 smaller than a 0,000 .

\section{CONCLUSION}

Based on the results of the discussion, the following conclusions were obtained:

\section{Simultaneous Influence}

The simultaneous influence of Leadership Orientation and Rewards on Employee Loyalty is shown from the results of the statistical analysis of the coefficient of determination (R2) with the amount of Adjusted R Square of 0.321 or $32.1 \%$. Means that the contribution of leadership orientation and appreciation simultaneously to employee loyalty is $32.1 \%$, while the remaining $67.9 \%$ is explained by other variables outside the research variable. A combination of Leadership Orientation and good appreciation can increase employee loyalty. Vice versa, a combination of leadership orientation and appreciation that is not good can reduce employee loyalty.

\section{Partial Influence}

Multiple regression analysis shows that supervision has an influence on employee work discipline by 0.435 , meaning that if the leadership orientation is increased by 1 unit it will increase work loyalty by 0.435 units. While awards have an influence on employee loyalty by 0.279 , meaning that if the award is increased by 1 unit it will increase employee loyalty by 0.279 units. Leadership orientation is the dominant factor influencing employee loyalty at Lancang Kuning University Pekanbaru. Loyalty in general includes both qualitative and quantitative aspects of the implementation of work, an increase in leadership and rewards can increase employee loyalty, conversely a decrease in leadership orientation and rewards can reduce employee loyalty. 


\section{REFERENCES}

Antoncic, B. (2016). Employee loyalty and its impact on firm growth. International Journal of Management \& Information Systems. 15(1), 81-88.

Bungin, Burhan. (2015). Metodologi Penelitian Kualitatif: Depok, Rajagrafindo Pustaka.

Dessler, Gary. (2015). Manajemen Sumber Daya Manusia. Jakarta: Salemba Empat.

Ghozali, Imam. (2013). Aplikasi Analisis Multivariate dengan Program IBM SPSS 19, Semarang: Badan Penerbit Universitas Diponegoro

Hasibuan, Malayu S.P. (2016). "Manajemen Sumber Daya Manusia”. Edisi Revisi. Jakarta: Penerbit PT Bumi Aksara.

Hasibuan, Malayu S.P, (2014). Manajemen Sumber Daya Manusia. Jakarta : Bumi Aksara.

Handoko T. Hani, (2014). Manajemen Personalia dan Sumber Daya Manusia. BPFE-Yogyakarta. Yogyakarta

Martiwi, R. T. (2014). Faktor-faktor Penentu yang Mempengaruhi Loyalitas Kerja Karyawan. Daya Saing Jurnal Ekonomi Manajemen Sumber Daya, 13 (1), 44-52.

Marwansyah. (2016). Manajemen Sumber Daya Manusia, Edisi Dua. Cetakan keempat. Bandung : Alfabeta,CV

Robbins, Stephen P. dan Coulter, Mary. (2016). Manajemen, Edisi kesepuluh. Jakarta : Erlangga.

Sadili, Samsudin. (2014). Manajemen Sumber Daya Manusia. Jakarta : CV Pustaka Setia.

Sedarmayanti, (2013). Manajemen Sumber Daya Manusia. Bandung : Refika Aditama.

Siagian, P. Sondang. (2016). Teori dan Praktek Kepemimpinan. Jakarta : Rineka Cipta.

Sunyoto, Danang. (2015). Penelitian Sumber Daya Manusia. Yogyakarta: PT Buku Seru

Sutikno, Sobry M. (2014). Pemimpin dan Orientasi Kepemimpinan , Edisi Pertama Lombok: Holistica

Sutrisno, Edy. (2016). Manajemen Sumber Daya Manusia. Bandung: PT. Mulia Kencana Semesta

Sugiyono. (2016). Metode Penelitian Kuantitatif Kualitatif dan Kombinasi (Mixed Methods). Bandung: Alfabeta.

Syarifah F. (2014). Pengaruh Gaya Kepemimpinan Terhadap Kinerja Karyawan Pada Kebun Rimba Belian Inti Kabupaten Sanggau. Program Studi Ilmu Administrasi Negara. Fakultas Ilmu Sosial dan Ilmu Politik. Universitas Tanjungpur : Pontianak

Thofa, Miftah. (2013). Kepemimpinan dalam Manajemen. PT. Raja Grafindo Persada, Jakarta.

Y. Ruyatnasih. (2013). Pengaruh Gaya Kepemimpinan Terhadap Kinerja Karyawan PT. Mitrabuana Jayalestari Karawang Jurnal Manajemen Vol. 10 No. $31-18$

Veithzal Rivai. (2014). Manajemen Sumber Daya Manusia Untuk Perusahaan. PT. Rajagrafindo Persada. Jakarta. 